Article

\title{
Aqueous Liquid-Liquid Phase Separation of Natural and Synthetic Polyguanidiniums
}

\author{
Leland J. Prather ${ }^{1}$, G. Mahika Weerasekare ${ }^{1}$, Monika Sima ${ }^{1}$, Colette Quinn ${ }^{2}$ \\ and Russell J. Stewart ${ }^{1, *}$ \\ 1 Department of Biomedical Engineering, University of Utah, Salt Lake City, UT 84112, USA; \\ 1.jack.prather@gmail.com (L.J.P.); mahikaw@yahoo.com (G.M.W.); ms57@utah.edu (M.S.) \\ 2 TA Instruments, 890 W 410 N St, Lindon, UT 84042, USA; cquinn@tainstruments.com \\ * Correspondence: russell.stewart@utah.edu; Tel.: +1-(801)-581-8581
}

Received: 22 February 2019; Accepted: 4 April 2019; Published: 9 April 2019

\begin{abstract}
Protamines are natural polyguanidiniums, arginine(R)-rich proteins involved in the compaction of chromatin during vertebrate spermatogenesis. Salmine, a protamine isolated from salmon sperm, contains $65 \mathrm{~mol} \% \mathrm{R}$ residues, with positively charged guanidino $\left(\mathrm{Gdm}^{+}\right)$ sidechains, and no other amino acids with ionizable or aromatic sidechains. Salmine sulfate solutions undergo liquid-liquid phase separation (LLPS) with a concentration-dependent upper critical solution temperature (UCST). The condensed liquid phase comprises $50 \mathrm{wt} \%$ water and $>600 \mathrm{mg} \cdot \mathrm{mL}^{-1}$ salmine with a constant 1:2 ratio of sulfate $\left(\mathrm{SO}_{4}{ }^{2-}\right)$ to $\mathrm{Gdm}^{+}$. Isothermal titration calorimetry, titrating $\mathrm{Na}_{2} \mathrm{SO}_{4}$ into salmine chloride above and below the UCST, allowed isolation of exothermic sulfate binding to salmine chloride from subsequent endothermic condensation and exothermic phase separation events. Synthetic random polyacrylate analogs of salmine, with 3-guanidinopropyl sidechains, displayed similar counterion dependent phase behavior, demonstrating that the LLPS of polyguanidiniums does not depend upon subunit sequence or polymer backbone chirality, and was due entirely to $\mathrm{Gdm}^{+}$sidechain interactions. The results provide experimental evidence for like-charge pairing of $\mathrm{Gdm}^{+}$sidechains, and an experimental approach for further characterizing these interactions.
\end{abstract}

Keywords: liquid-liquid phase separation; complex coacervation; $\mathrm{Gdm}^{+}$like-charge pairing; protamine; salmine; guanidinium; polyguanidinium

\section{Introduction}

Complex coacervation, a type of liquid-liquid phase separation (LLPS), occurs when attractive interactions between solvated macromolecules are strong enough to condense the macromolecules into a separate phase, yet are weak and dynamic enough that the condensed phase forms a fluid network, rather than a solid precipitate or ionic hydrogel [1]. In suitable solution conditions, all types of non-covalent interactions between macromolecules, including ion pairing, $\mathrm{H}$-bonding, $\pi-\pi, \pi$-cation, and metal-ligand interactions, can promote LLPS by complex coacervation [2-4]. Cellular LLPS creates transient, phase-defined cytoplasmic compartments, also called membraneless organelles, in response to external stimuli [5-9]. A growing list of proteins known to condense in the cytoplasm and in vitro, contain polycationic arginine-rich motifs [10-15], pointing to the importance of arginines (R) in the intermolecular associations that lead to cellular LLPS. Enzymatic methylation of Rs diminishes the LLPS of R-rich Ddx4 [11] and FUS [8,15,16], which suggests cellular LLPS may be regulated, at least in part, through enzymatic R methylation, further highlighting the role of Rs in cellular LLPS. Disruption of normal cellular LLPS, or gain-of-function mutations that cause abnormal cellular LLPS, lead to pathology, examples of which include neurodegenerative diseases [17-19]. Therefore, 
better understanding of the molecular mechanisms of R-mediated LLPS may provide insights into fundamental cell biology, and have important implications for health and disease.

Protamines are small, R-rich proteins that replace histones during spermatogenesis to compact chromatin into the sperm heads of vertebrates [20]. In vitro associative LLPS of purified protamine sulfate was reported in the early 20th century when Kossel described the "condensation of an oily precipitate" from a warm aqueous solution of protamine sulfate as it cooled [21]. Salmine is a protamine isolated from salmon sperm comprising 32 amino acid residues, of which 21 are R [22]. Salmine contains no other charged or aromatic amino acids. As such, salmine is a convenient and readily available R-rich protein with which to investigate the role of R-R interactions in associative LLPS in the absence of other electrostatic or $\pi$-cation interactions. Here, we describe initial physicochemical characterization of the in vitro LLPS of salmine. The temperature, concentration, and counter-ion dependence, as well as the thermodynamics of the condensation reaction are described. To show that the condensation is mediated through association of $\mathrm{R}-\mathrm{Gdm}^{+}$sidechains, the phase behavior of a series of poly(3-guanidinopropyl methacrylamide-co-acrylamide) random copolymers-synthetic salmine analogs-were partially characterized for comparison.

\section{Materials and Methods}

\subsection{Salmine Sulfate and Salmine Chloride}

USP grade salmine sulfate, obtained from MP Biomedicals, Inc., Santa Ana, CA, USA (CAS: 9009-65-8). The $\mathrm{M}_{\mathrm{m}}$ of the salmine-AI GenBank sequence (accession number X07511.1, (MPRRRRSSSR PVRRRRRPRVSRRRRRRGGRRRR), $4381 \mathrm{~g} \cdot \mathrm{mol}^{-1}$, was used to estimate the concentrations of positively charged guanidino $\left(\mathrm{Gdm}^{+}\right)$sidechains (21/32 amino acids) and molar ratios of $\mathrm{Gdm}^{+}$to sulfate $\left(\mathrm{SO}_{4}{ }^{2-}\right)$ in salmine solutions. For example, the $\left[\mathrm{Gdm}^{+}\right]$in a $50 \mathrm{mg} \mathrm{mL}^{-1}$ solution was estimated to be $194 \mathrm{mM}$ from the sequence, and the $\left[\mathrm{SO}_{4}{ }^{2-}\right]$ as $99 \mathrm{mM}$ from elemental analysis of the as-received salmine sulfate. The $\mathrm{SO}_{4}{ }^{2-}: \mathrm{Gdm}^{+}$molar ratio was 0.51 . To convert salmine sulfate to the chloride form, it was dissolved in ultrapure deionized water at $10 \mathrm{mg} \mathrm{mL}^{-1}$, then passed through an ion exchange column, Amberlite IRA-400 HCl (Aldrich, CAS: 60177-39-1, St. Louis, MO, USA). The exchanged protamine was dialyzed to remove excess salt, then lyophilized. The phosphate and acetate forms of salmine were prepared by similar ion exchange processes on Amberlite resins.

\subsection{Coacervate Characterization}

The salmine concentrations in the coacervate phase and the supernatant were determined by quantitative nuclear magnetic resonance (NMR) using $t$-butanol as an internal standard [23]. In a typical experiment, a $100 \mathrm{mg} \cdot \mathrm{mL}^{-1}$ solution of salmine sulfate at $\mathrm{pH} 7$ was heated to $65^{\circ} \mathrm{C}$, mixed with a $1 \mathrm{M}$ solution of $\mathrm{Na}_{2} \mathrm{SO}_{4}$ at $65^{\circ} \mathrm{C}$, then diluted to a final concentration of $50 \mathrm{mg} \mathrm{mL}^{-1}$ salmine sulfate $\left(194 \mathrm{mM} \mathrm{Gdm}^{+}\right)$. The solution was then equilibrated at a given temperature overnight. The two phases were separated at that temperature and lyophilized. The dried coacervate and the dried supernatant phase were then dissolved separately in $\mathrm{D}_{2} \mathrm{O}$ and $1.5 \mathrm{M} \mathrm{HCl}$ in $\mathrm{D}_{2} \mathrm{O}$, once dissolved, $t$-butanol in $\mathrm{D}_{2} \mathrm{O}$ was added to the solutions. The integral of $t$-butanol signal (1.03 ppm) was set to 1.00 . The integral for arginine $\delta \mathrm{CH}_{2}$ (3.01 ppm) was used to calculate the percent protamine in the coacervate and supernatant. A similar method substituting ethylene glycol (3.40 ppm) for $t$-butanol was used to calculate the amount of poly(3-guanidinopropyl methacrylamide-co-acrylamide) in the coacervate and supernatant as the $t$-butanol proton signals overlap with the backbone proton signals of the polymer.

Coacervate yield and water content was determined gravimetrically. Salmine sulfate and salmine chloride were dissolved at a concentration of $50 \mathrm{mg} \cdot \mathrm{mL}^{-1}$ in varying concentrations of $\mathrm{Na}_{2} \mathrm{SO}_{4}$, or $\mathrm{NaCl}$ solutions. The solutions were equilibrated overnight at $8{ }^{\circ} \mathrm{C}$. After separating the supernatant and coacervate, the mass and volume of each phase was determined before lyophilization. 
The wet weight compared to the dry weight was used to determine the wt $\%$ water in the coacervate phase. The coacervate yield was determined from the dry weight and wet volume. ICP-OES was used to determine the molar ratio of $\mathrm{S}$ to $\mathrm{Gdm}^{+}$in the coacervate.

\subsection{Phase Transition Temperature Determination by Turbidity}

Turbidity at $600 \mathrm{~nm}$ was determined in a Lamda Bio 20 UV/Vis Spectrometer (PerkinElmer, Waltham, MA, USA). Neither salmine nor poly(3-guanidinopropyl methacrylamide-co-acrylamide) solutions absorb light at $600 \mathrm{~nm}$. The temperature within the spectrometer was controlled using a Peltier system (Perkin Elmer, PTP-6, Waltham, MA, USA) with a precision of $0.1^{\circ} \mathrm{C}$. Each sample was initially heated to $60^{\circ} \mathrm{C}$, and then lowered in $1{ }^{\circ} \mathrm{C}$ increments until the transmission fell to $70 \%$ of its initial value, which was recorded as the liquid-liquid phase separation (LLPS) upper critical solution temperature (UCST).

\subsection{Isothermal Titration Calorimetry (ITC)}

An Affinity ITC LV isothermal titration calorimeter (TA Instruments, New Castle, DE, USA) was used to determine the enthalpic and entropic changes resulting from the titration of salmine chloride (10 $\mathrm{mg} \cdot \mathrm{mL}^{-1}, 41.4 \mathrm{mM} \mathrm{R}$ ) with a solution of $\mathrm{Na}_{2} \mathrm{SO}_{4}(400 \mathrm{mM})$ above the phase transition temperature $\left(25^{\circ} \mathrm{C}\right)$ and below the phase transition temperature $\left(10^{\circ} \mathrm{C}\right)$. Prior to the first injection, the system was equilibrated to a medium setting of $0.3 \mu \mathrm{W} \cdot \mathrm{hr}^{-1}$ and $0.03 \mu \mathrm{W}$ standard error. Thirty-five one $\mu \mathrm{L}$ injections of $400 \mathrm{mM} \mathrm{Na}_{2} \mathrm{SO}_{4}$ were injected into an active cell volume of $185 \mu \mathrm{L}$ of salmine chloride. Each injection was delivered over $2 \mathrm{~s}$ with $200 \mathrm{~s}$ between successive injections. The injection syringe was attached to a paddle, and the solution was stirred at $100 \mathrm{rpm}$ during the assay. Data is plotted in $\mathrm{Js}^{-1}$, and exothermic events are downward peaks in the thermograms.

A thermogram of $400 \mathrm{Mm}$ of $\mathrm{Na}_{2} \mathrm{SO}_{4}$ injected into a $\mathrm{NaCl}$ solution $(41.4 \mathrm{mM})$ without the salmine produced constant heat, which served as a negative control, and the background heat of dilution. The $[\mathrm{NaCl}]$ was equivalent to the amount of $\mathrm{Cl}^{-}$present in the salmine chloride sample to avoid ionic strength effects. salmine ITC thermograms were corrected for this background heat of dilution, $443.6 \mu \mathrm{J}$ and $816.6 \mu \mathrm{J}$ for the 25 and $10^{\circ} \mathrm{C}$ experiments, respectively. Data acquisition and analyses were performed using NanoAnalyze ${ }^{\circledR}$ (TA Instruments, New Castle, DE, USA) which was supplied with the instrument. The one-site model, provided with the software, was used to fit binding isotherms above the UCST $\left(25^{\circ} \mathrm{C}\right)$. The one-site and multiple-sites model were both used to fit binding isotherms below the UCST $\left(10^{\circ} \mathrm{C}\right)$. Thermodynamic parameters, including the binding constant $\left(\mathrm{K}_{\mathrm{a}}\right)$, binding stoichiometry $(\mathrm{n})$, change in enthalpy $(\Delta \mathrm{H})$, and change in entropy $(\Delta \mathrm{S})$ were calculated by iterative curve fitting of the binding isotherms. The models used to fit the data have been described previously [24].Measurements were carried out in duplicate.

\subsection{Synthesis of N-(3-methacrylamidopropyl)guanidinium Chloride}

$\mathrm{N}$-(3-Methacrylamidopropyl)guanidinium chloride was synthesized as previously described [25,26]. Briefly, a solution of $\mathrm{N}$-(3-aminopropyl)methacrylamide $\mathrm{HCl}$ (15 g, $84 \mathrm{mmol})$, 4-methoxyphenol (150 mg) and $\mathrm{N}, \mathrm{N}$-diisopropylethylamine $(38 \mathrm{~mL}, 209 \mathrm{mmol})$ in DMF $(85 \mathrm{~mL}$, keeping the final concentration of the reactants $2 \mathrm{M}$ ), was stirred for $5 \mathrm{~min}$ under argon. To this solution $1 \mathrm{H}$-pyrazole-1-carboxamidine monohydrochloride (12.3 g, $84 \mathrm{mmol})$ was added. The mixture was stirred at room temperature for $24 \mathrm{~h}$ under Ar, then poured into diethylether $(1200 \mathrm{~mL})$. The resulting oil was separated from the supernatant and washed twice with a solution of acetonitrile $(200 \mathrm{~mL})$ and triethylamine $(10 \mathrm{~mL})$. The resultant solid was washed with dichloromethane $(300 \mathrm{~mL})$ and dried under vacuum to yield $13.3 \mathrm{~g}(72 \%)$ of the product (3, Supplemental Figure S1). ${ }^{1} \mathrm{H}$ NMR $\left(400 \mathrm{MHz}, \mathrm{DMSO}-\mathrm{d}_{6}\right) \delta \mathrm{ppm} 8.09(\mathrm{~s}$, $1 \mathrm{H}), 7.91(\mathrm{~s}, 1 \mathrm{H}), 7.70-6.90(\mathrm{br}, 4 \mathrm{H}), 5.70(\mathrm{~s}, 1 \mathrm{H}), 5.33(\mathrm{~s}, 1 \mathrm{H}), 3.16(\mathrm{~m}, 4 \mathrm{H}), 1.87(\mathrm{~s}, 3 \mathrm{H}), 1.65$ (quin, $2 \mathrm{H})$. 


\subsection{Synthesis and Characterization of Poly(3-guanidinopropyl methacrylamide-co-acrylamide) $\mathrm{HCl}$}

$\mathrm{N}$-(3-methacrylamidopropyl)guanidinium $\mathrm{HCl}(3.85 \mathrm{~g}, 17.4 \mathrm{mmol})$, acrylamide $(0.64 \mathrm{~g}, 9 \mathrm{mmol})$, the RAFT agent 4-cyano-4-(thiobenzoylthio)pentanoic acid $(0.063 \mathrm{~g}, 0.23 \mathrm{mmol})$, and the initiator azobisisobutyronitrile $(7.4 \mathrm{mg}, 0.045 \mathrm{mmol})$ were dissolved in dimethyl sulfoxide (DMSO) $(25 \mathrm{~mL})$ and degassed for $30 \mathrm{~min}$. The solution was heated at $70{ }^{\circ} \mathrm{C}$ under argon for $40 \mathrm{~h}$, then cooled and the copolymer precipitated in acetone. The precipitated copolymer was dissolved in methanol. Azobisisobutyronitrile $(0.930 \mathrm{~g}, 5.7 \mathrm{mmol})$ was added, the solution was degassed for $30 \mathrm{~min}$, and heated at $60^{\circ} \mathrm{C}$ overnight to remove the RAFT agent. The solution was then cooled and the copolymer precipitated in acetone, filtered and dried. The final yield was $3.7 \mathrm{~g}$ or $83 \%$ (5, Supplemental Figure S1).

The mol\% 3-guanidinopropyl sidechains was determined by ${ }^{1} \mathrm{H}$ NMR (Supplmental Table S1). The $\mathrm{M}_{\mathrm{m}}$ and PDI of the copolymers were determined by size exclusion HPLC using a CATSEC-300 column (Eprogen, Downers Grove, IL, USA) on an Agilent 1260 Infinity instrument. The copolymers were run in $1 \mathrm{wt} \%$ acetic acid and $0.10 \mathrm{M} \mathrm{LiBr}$ in $\mathrm{HPLC}$ grade $\mathrm{H}_{2} \mathrm{O}$ at a flow rate of $1 \mathrm{~mL} \mathrm{~min}{ }^{-1}$ at $25^{\circ} \mathrm{C}$. The HPLC was equipped with a refractive index and miniDawn TREOS (Wyatt Technology, Santa Barbara, CA, USA) multi-angle light scattering detectors.

\subsection{Preparation of Poly(3-guanidinopropyl methacrylamide-co-acrylamide) Sulfate}

$1 \mathrm{M} \mathrm{Na}_{2} \mathrm{SO}_{4}(9 \mathrm{~mL})$ was added to an aqueous solution of poly(3-guanidinopropyl methacrylamide-co-acrylamide) $\mathrm{HCl}(500 \mathrm{mg})$ and stirred overnight. Two volumes of ethanol were added to precipitate the copolymer, which was then dissolved in $\mathrm{H}_{2} \mathrm{O}$, and re-precipitated by the addition of $9 \mathrm{~mL}$ of $1 \mathrm{M} \mathrm{Na}_{2} \mathrm{SO}_{4}$, followed by 2 volumes of ethanol. The precipitated copolymer was dissolved in $\mathrm{H}_{2} \mathrm{O}$ and passed through a column of IRA-400 anion exchange resin in sulfate form to ensure complete exchange of $\mathrm{Cl}^{-}$with $\mathrm{SO}_{4}{ }^{2-}$ [27]. The solution was lyophilized, dissolved in water and refrigerated to separate the polymer from inorganic salts. Dissolving in water and refrigerating was repeated three times. The separated polymer was dissolved in water and lyophilized to obtain poly(3-guanidinopropyl methacrylamide-co-acrylamide) sulfate in a $69 \%$ (360 mg) yield.

\section{Results}

\subsection{Condensation of Salmine Sulfate}

The temperature dependent self-association of polycationic salmine sulfate into a condensed liquid phase is shown in Figure 1. A clear $100 \mathrm{mg} \mathrm{mL}^{-1}$ solution of salmine containing $400 \mathrm{mM} \mathrm{Na}_{2} \mathrm{SO}_{4}$ at $60{ }^{\circ} \mathrm{C}$ (Figure 1A) was placed in a $20^{\circ} \mathrm{C}$ incubator to cool while the temperature of the solution was monitored. The solution abruptly turned cloudy at $45^{\circ} \mathrm{C}$, the upper critical solution temperature (UCST), as salmine sulfate associated into light scattering complexes (Figure 1B). The initial complexes condensed further into a cloudy liquid macrophase that spontaneously settled to the bottom of the bottle without centrifugation (Figure 1C). After $24 \mathrm{~h}$ at $20^{\circ} \mathrm{C}$, the condensed macrophase equilibrated into a transparent homogeneous liquid (Figure 1D, Supplemental Video S1).
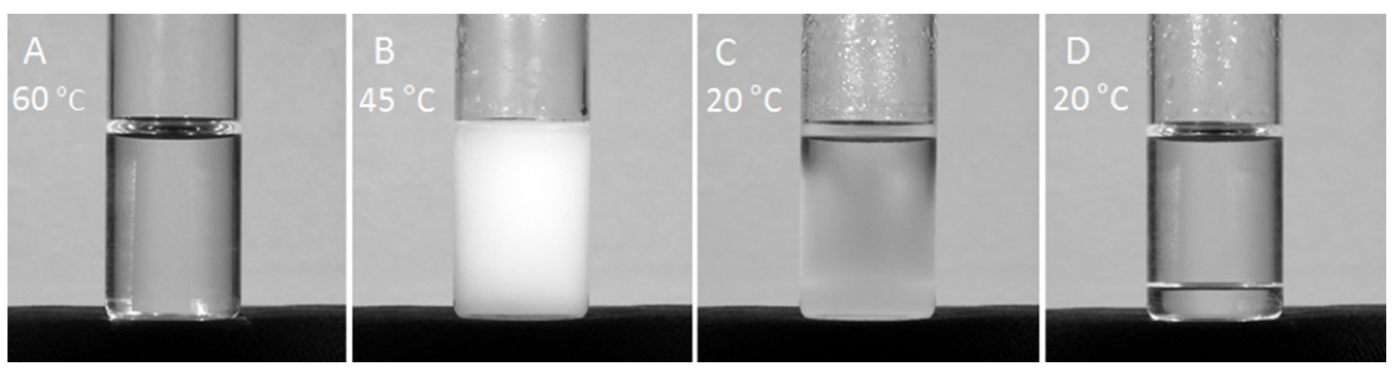

Figure 1. Temperature-dependent complex coacervation of salmine in $400 \mathrm{mM} \mathrm{Na}_{2} \mathrm{SO}_{4}$. (A) A solution of salmine sulfate $\left(100 \mathrm{mg} \cdot \mathrm{mL}^{-1}\right)$ at $60^{\circ} \mathrm{C}$. (B) As the clear solution cooled, it became turbid at $45^{\circ} \mathrm{C}$ 
when salmine sulfate condensed into complexes. (C) The complexes coalesced and spontaneously ( $1 \mathrm{~g}$ ) settled out as a dense liquid precipitate. (D) After $24 \mathrm{~h}$ at $20^{\circ} \mathrm{C}$, the macrophase equilibrated into a clear homogeneous dense liquid.

\subsection{Temperature (T) and Concentration Dependence of Salmine Sulfate Condensation}

The percent of total salmine $\left(50 \mathrm{mg} \cdot \mathrm{mL}^{-1}\right)$ in the condensed phase, referred to as yield, was determined as a function of $\mathrm{T}$ (Figure $2 \mathrm{~A}$ ). A $50 \mathrm{mg} \cdot \mathrm{mL}^{-1}$ solution of salmine sulfate was estimated to comprise $194 \mathrm{mM} \mathrm{Gdm}^{+}$sidechains and, as received, contained $99 \mathrm{mM} \mathrm{SO}_{4}{ }^{2-}$, corresponding to an approximately 0.5:1 molar ratio of $\mathrm{SO}_{4}{ }^{2-}$ to $\mathrm{Gdm}^{+}$(see methods). $\mathrm{Na}_{2} \mathrm{SO}_{4}$ was added to a total of $200 \mathrm{mM}$ for an approximate 1:1 molar ratio of $\mathrm{Gdm}^{+}$to $\mathrm{SO}_{4}{ }^{2-}$. At $8{ }^{\circ} \mathrm{C}$ and below, nearly $100 \%$ of the salmine partitioned into the condensed phase. As $\mathrm{T}$ increased, the yield of condensed salmine decreased to $0 \%$ at $45^{\circ} \mathrm{C}$, corresponding to the phase transition temperature observed in Figure $2 \mathrm{~B}$. The salmine concentration dependence of the UCST — the cloud point temperature-was determined turbidimetrically (Figure $2 \mathrm{~B}$ ). The $\mathrm{Gdm}^{+}$to $\mathrm{SO}_{4}{ }^{2-}$ molar ratio was adjusted to 1:1 to match the solution conditions of the temperature experiments. At $2.5 \mathrm{mg} \cdot \mathrm{mL}^{-1}$, the UCST was $15{ }^{\circ} \mathrm{C}$, and rose with increasing concentration until plateauing at $45^{\circ} \mathrm{C}$, at approximately $70 \mathrm{mg} \cdot \mathrm{mL}^{-1}$. The UCST was not determined for salmine concentrations greater than $100 \mathrm{mg} \cdot \mathrm{mL}^{-1}$.
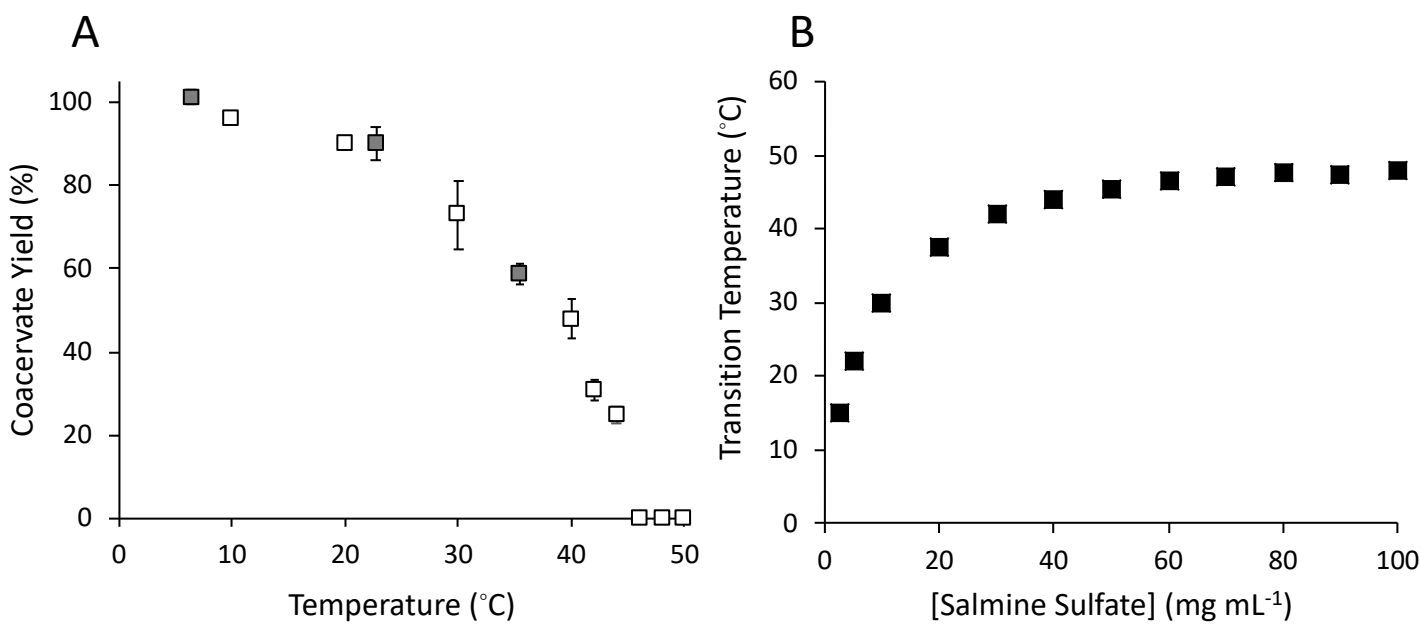

Figure 2. (A) Temperature dependence of condensed phase yield. Salmine $=50 \mathrm{mg} \cdot \mathrm{mL}^{-1}$, sulfate $\left(\mathrm{SO}_{4}{ }^{2-}\right)$ $=200 \mathrm{mM}, \mathrm{R}-\mathrm{Gdm}^{+}: \mathrm{SO}_{4}{ }^{2-}=1: 1$. Open symbols were determined by nuclear magnetic resonance $(\mathrm{NMR})$. Grey squares were determined gravimetrically. Mean $\pm 1 \mathrm{SD}(\mathrm{n}=3)$. (B) Concentration dependence of the phase transition temperature with 1:1 molar ratios of positively charged guanidino $\left(\mathrm{Gdm}^{+}\right)$to $\mathrm{SO}_{4}{ }^{2-}$.

\subsection{Counter-Anion Dependence of Salmine Condensation}

Sulfate concentration effects on salmine UCST were investigated by turbidimetry. The UCST of a $50 \mathrm{mg} \cdot \mathrm{mL}^{-1}$ solution of salmine sulfate, as received without addition of $\mathrm{Na}_{2} \mathrm{SO}_{4}$, was $32{ }^{\circ} \mathrm{C}$. Addition of $\mathrm{Na}_{2} \mathrm{SO}_{4}$ to a total of $200 \mathrm{mM}$, an approximate $1: 1$ molar ratio of $\mathrm{Gdm}^{+}$to $\mathrm{SO}_{4}{ }^{2-}$, increased the UCST to $45^{\circ} \mathrm{C}$. Above $300 \mathrm{mM} \mathrm{SO}_{4}{ }^{2-}$, the UCST decreased slightly, then remained constant up to $800 \mathrm{mM}$ $\mathrm{SO}_{4}{ }^{2-}$ (Figure $3 \mathrm{~A}$ ). The UCST of salmine exchanged with $\mathrm{HPO}_{4}{ }^{2-}$ was significantly lower than salmine sulfate, peaking at approximately $18{ }^{\circ} \mathrm{C}$ in $200 \mathrm{mM} \mathrm{HPO}_{4}{ }^{2-}$ at a 1:1 molar ratio. It was not possible to test $\mathrm{HPO}_{4}{ }^{2-}$ greater than $500 \mathrm{Mm}$, due to solubility limitations. Nevertheless, the limited data suggested that high $\left[\mathrm{HPO}_{4}{ }^{2-}\right]$ suppressed the UCST more strongly than high $\left[\mathrm{SO}_{4}{ }^{2-}\right]$. 

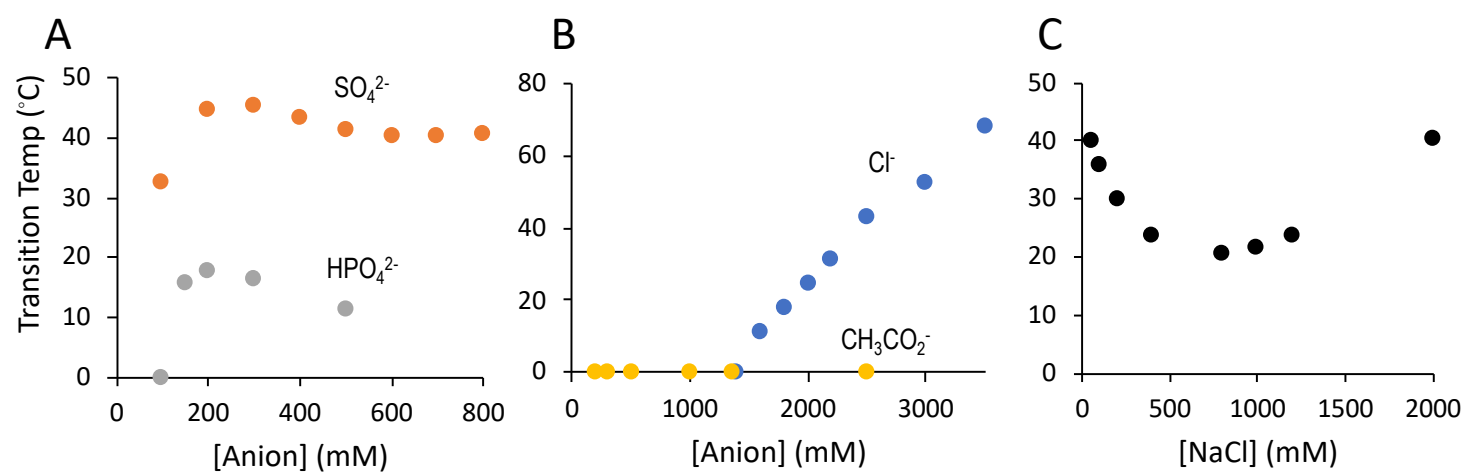

Figure 3. Counter-anion effects on salmine $\left(50 \mathrm{mg} \cdot \mathrm{mL}^{-1}\right)$ upper critical solution temperature (UCST) determined by turbidimetry. (A) Dianions: Salmine sulfate (orange) and salmine phosphate dibasic (grey). (B) Monoanions: Salmine acetate (yellow) and salmine chloride (blue). (C) Effect of $\mathrm{NaCl}$ on the UCST of $50 \mathrm{mg} \cdot \mathrm{mL}^{-1}$ salmine and $200 \mathrm{mM} \mathrm{Na}_{2} \mathrm{SO}_{4}$.

The UCST is a direct measure of the stability of the intermolecular associations between salmine molecules that lead to condensation and phase separation. Based on the lower UCST, dianionic $\mathrm{HPO}_{4}{ }^{2-}$ promoted significantly weaker intermolecular associations between salmine molecules than $\mathrm{SO}_{4}{ }^{2-}$ dianions. The weak effect on UCST of high $\left[\mathrm{SO}_{4}{ }^{2-}\right]$ suggested that excess $\mathrm{SO}_{4}{ }^{2-}$ ions do not competitively interfere with intermolecular associations that lead to condensation. On the other hand, excess $\mathrm{HPO}_{4}{ }^{2-}$ ions may competitively saturate $\mathrm{Gdm}^{+}$sidechains preventing intermolecular ionic interactions.

The compositions of the condensed phases were determined at total $\mathrm{SO}_{4}{ }^{2-}$ concentrations of $99,200,400$, and $800 \mathrm{mM}$ (Table 1). There were no statistically significant differences in the condensed phases with respect to salmine concentration, water content, or the $\mathrm{SO}_{4}{ }^{2-}$ to $\mathrm{Gdm}^{+}$molar ratio. The salmine concentration was greater than $600 \mathrm{mg} \cdot \mathrm{mL}^{-1}$, representing a 12 -fold spontaneous concentration of salmine into the condensed phase. The water concentration was approximately $50 \mathrm{wt} \%$ and the $\mathrm{SO}_{4}{ }^{2-}$ to $\mathrm{Gdm}^{+}$molar ratio was approximately 0.5 at all $\left[\mathrm{SO}_{4}{ }^{2-}\right]$. The consistent molar ratio demonstrated that two positive $\mathrm{Gdm}^{+}$sidechains were balanced by one $\mathrm{SO}_{4}{ }^{2-}$ dianion in the condensed phases, independent of the total $\left[\mathrm{SO}_{4}{ }^{2-}\right]$. The sulfate-mediated condensation is therefore due to specific intermolecular interactions, formation of stoichiometric complexes, rather than a solution effect or 'salting out' phenomenon. The constant condensed phase stoichiometry is consistent with the minimal effect of $\left[\mathrm{SO}_{4}{ }^{2-}\right]$ on the UCST; excess $\left[\mathrm{SO}_{4}{ }^{2-}\right]$ does not competitively disrupt the stoichiometric intermolecular binding of $\mathrm{SO}_{4}{ }^{2-}$ to $\mathrm{Gdm}^{+}$sidechains that leads to condensation and associative macrophase separation.

Monovalent anions had dramatically different effects on salmine phase separation than divalent anions. Acetate ions did not promote LLPS at any concentration up to $2.5 \mathrm{M}$. Chloride ions, on the other hand, at concentrations of $1.4 \mathrm{M}$ and higher induced LLPS with UCSTs that increased steadily with $\mathrm{Cl}^{-}$concentrations up to $3.5 \mathrm{M}$ (Figure 3B). The salmine concentration increased and water content decreased in the liquid coacervate phase as the $\mathrm{NaCl}$ increased (Table 1). It required about 10-fold higher concentrations of $\mathrm{Cl}^{-}$than $\mathrm{SO}_{4}{ }^{2-}$ to induce LLPS. Addition of $\mathrm{NaCl}$ to salmine solutions with a 1:1 ratio of $\mathrm{Gdm}^{+}$to $\mathrm{SO}_{4}{ }^{2-}$ suppressed UCST at low concentrations, then increased UCST at concentrations above $0.8-1 \mathrm{M}$ (Figure $3 \mathrm{C}$ ). 
Table 1. Composition of salmine coacervate phases.

\begin{tabular}{|c|c|c|c|}
\hline Total [anion] (mM) & Salmine (mg mL $\left.{ }^{-1}\right)$ & Water $(w t \%)$ & Molar Ratio $\mathrm{SO}_{4}{ }^{2-}$ to $\mathrm{Gdm}^{+}$ \\
\hline \multicolumn{4}{|c|}{ Salmine Sulfate } \\
\hline 99 & $617 \pm 33$ & $49.8 \pm 2.2$ & $0.43 \pm 0.03$ \\
\hline 200 & $634 \pm 68$ & $50.0 \pm 4.0$ & $0.44 \pm 0.09$ \\
\hline 400 & $602 \pm 11$ & $47.8 \pm 0.5$ & $0.47 \pm 0.00$ \\
\hline 800 & $643 \pm 46$ & $47.0 \pm 1.5$ & $0.47 \pm 0.01$ \\
\hline \multicolumn{4}{|c|}{ Salmine Chloride } \\
\hline 1400 & $465 \pm 58$ & $66.8 \pm 4.3$ & - \\
\hline 1500 & $511 \pm 11$ & $60.9 \pm 2.7$ & - \\
\hline 1700 & $553 \pm 27$ & $56.0 \pm 0.8$ & - \\
\hline 2000 & $616 \pm 17$ & $55.3 \pm 2.7$ & - \\
\hline 2200 & $626 \pm 6$ & $52.2 \pm 1.4$ & - \\
\hline 2500 & $637 \pm 6$ & $48.5 \pm 2.4$ & - \\
\hline
\end{tabular}

Mean \pm s.d., $\mathrm{n} \geq 3$ for all measurements.

\subsection{Isothermal Titration Calorimetry (ITC)}

Heat flow associated with salmine sulfate condensation and phase separation were measured by isothermal titration calorimetry (ITC) to calculate the thermodynamic parameters of the reaction. A solution of salmine chloride $\left(10 \mathrm{mg} \cdot \mathrm{mL}^{-1}, 41.4 \mathrm{mM} \mathrm{Gdm}^{+}\right)$was titrated with a solution of $400 \mathrm{mM}$ $\mathrm{Na}_{2} \mathrm{SO}_{4}$ at $25^{\circ} \mathrm{C}$, above the UCST (Figure $4 \mathrm{~A}$ ). The thermograms from above the UCST show the heat flow due to sulfate ions binding to salmine chloride without the effects of heat flow due to intermolecular complexation and subsequent condensation of salmine sulfate. This control experiment enabled deconvolution and assignment of events to the titration data collected below the UCST. To our knowledge, there is no precedent literature wherein the effects of ionic interactions and counterion displacement were separated from subsequent condensation by titrating above and below the phase transition temperature. Most reports describing the thermodynamics of LLPS (complex coacervation) by ITC were done by titrating one polyelectrolyte (or polyampholyte) into a second oppositely charged polyelectrolyte at a temperature conducive to intermolecular complexation and phase separation (see ref. [27] for a recent review). Heat flow resulting from initial ionic interactions and counterion release were superimposed on heat flow from subsequent events during polyelectrolyte condensation.

Thermodynamic parameters were calculated for the $25{ }^{\circ} \mathrm{C}$ (above UCST) thermogram (Figure 4B) by fitting with a one-site model using software (Nanoanalyze $\left.{ }^{\circledR}\right)$ supplied with the ITC instrument (Table 2, row 1). After subtracting the background heat of dilution of $\mathrm{Na}_{2} \mathrm{SO}_{4}{ }^{2-}$, the sulfate reaction with salmine chloride was exothermic, with a small enthalpic and a larger entropic contribution to the overall favorable change in free energy. The events contributing to the heat flow were likely the displacement of $\mathrm{Cl}^{-}$counterions by $\mathrm{SO}_{4}{ }^{2-}$ ions, the enthalpically favorable formation of $\mathrm{H}$-bonds between the $\mathrm{SO}_{4}{ }^{2-}$ oxygens and $\mathrm{Gdm}^{+}$hydrogens, and the entahalpically disfavored release of $\mathrm{H}_{2} \mathrm{O}$ from the hydration shells of $\mathrm{SO}_{4}{ }^{2-}$ and $\mathrm{Gdm}^{+}$. The calculated 0.45 binding stoichiometry $(\mathrm{N})$, a 1:2 molar ratio of $\mathrm{SO}_{4}{ }^{2-}$ to $\mathrm{Gdm}^{+}$, was consistent with the molar ratios determined by elemental analysis in the condensed phases (Table 1). The $25^{\circ} \mathrm{C}$ ITC binding stoichiometry suggested that specific complexes are formed between two $\mathrm{Gdm}^{+}$sidechains and one $\mathrm{SO}_{4}{ }^{2-}$ ion in the absence of macroscale condensation. In other words, pairing of $\mathrm{Gdm}^{+}$sidechains by $\mathrm{SO}_{4}{ }^{2-}$ ions is intramolecular rather than intermolecular, above the UCST. 
A
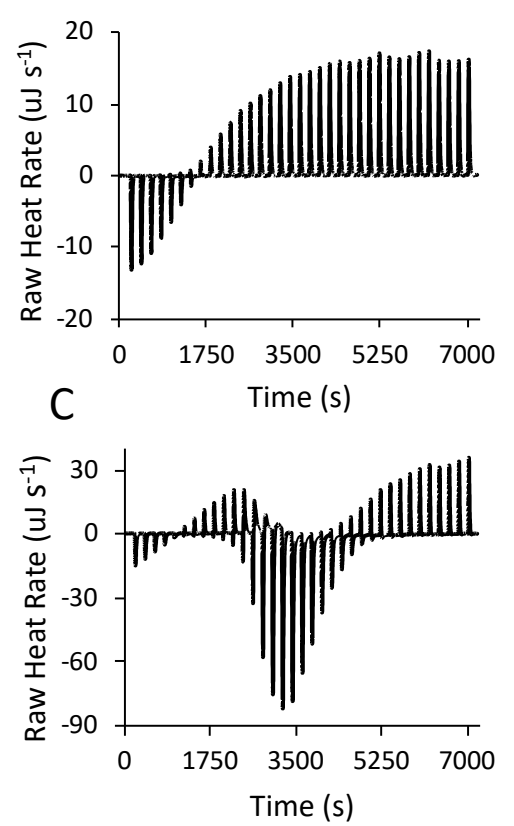

B
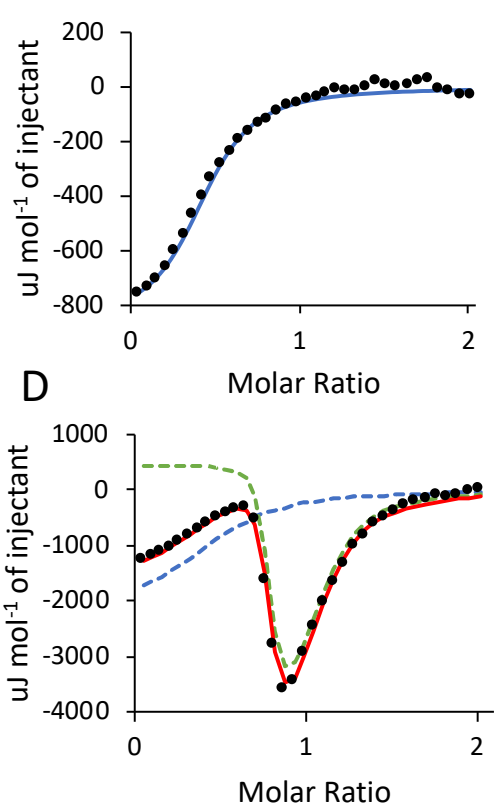

Figure 4. ITC thermograms of $\mathrm{Na}_{2} \mathrm{SO}_{4}$ titration into salmine chloride. (A) Raw heat flow rate per injection above the UCST at $25^{\circ} \mathrm{C}$. (B) A single-site binding model was fit (blue curve) to the integrated heat flow data (black symbols). (C) Raw heat flow rate per injection below the UCST at $10^{\circ} \mathrm{C}$. (D) The single-site (blue dashed curve) and a multiple independent site model (green dashed curve) were fit to the integrated heat flow data (black symbols). The red curve is the simultaneous fit of both models.

Table 2. ITC Thermodynamic Parameters.

\begin{tabular}{|c|c|c|c|c|c|}
\hline Temperature $\left({ }^{\circ} \mathrm{K}\right)$ & $\mathbf{N}$ & $\mathrm{K}_{\mathrm{a}}\left(\mathrm{M}^{-1}\right)$ & $\mathrm{H}\left(\mathrm{kJ} \mathrm{mol}{ }^{-1}\right)$ & $-\mathrm{T} \Delta \mathrm{S}\left(\mathrm{kJ} \mathrm{mol}{ }^{-1}\right)$ & $\mathrm{G}\left(\mathrm{kJ} \mathrm{mol}{ }^{-1}\right)$ \\
\hline $298.15 *$ & 0.45 & $3.96 \times 10^{2}$ & -2.18 & -12.65 & -14.83 \\
\hline 283.15 & 0.49 & $2.09 \times 10^{2}$ & -5.45 & -7.13 & -12.58 \\
\hline 283.15 & 0.76 & $1.15 \times 10^{5}$ & 1.15 & -28.60 & -27.45 \\
\hline 283.15 & 0.33 & $4.90 \times 10^{2}$ & -11.71 & -2.87 & -14.58 \\
\hline
\end{tabular}

* Above the phase transition temperature. $\mathrm{N}=$ binding stoichiometry.

Below the UCST at $10{ }^{\circ} \mathrm{C}$, three sequential events were apparent from inflections in the thermogram when salmine chloride $\left(10 \mathrm{mg} \mathrm{mL}^{-1}\right)$ was titrated with $400 \mathrm{mM} \mathrm{Na}_{2} \mathrm{SO}_{4}$ (Figure $4 \mathrm{C}$ ). (The UCST at $10 \mathrm{mg} \mathrm{mL}^{-1}$ is lower than in Figure 2B because of the presence of $\mathrm{Cl}^{-}$.) The data were fitted simultaneously with both the one-site model (Figure 4D, blue dashed curve) and a multiple non-interacting sites (MNIS) model provided with Nanoanalyze ${ }^{\circledR}$ (Figure 4D, green dashed curve). The calculated parameters from the one-site model were consistent with the parameters obtained for $\mathrm{SO}_{4}{ }^{2-}$ binding above the UCST; heat flow induced by interactions of $\mathrm{SO}_{4}{ }^{2-}$ with salmine chloride were exothermic, and driven both enthalpically and entropically (Table 2, row 2). There were small differences in the $10^{\circ} \mathrm{C} \Delta \mathrm{H}$ and $\Delta \mathrm{S}$ compared to $25^{\circ} \mathrm{C}$, because the temperature dependence of the heat capacity $\left(\Delta \mathrm{C}_{\mathrm{p}}=\mathrm{dH} / \mathrm{dT}\right)$ is not zero. However, the magnitude and stoichiometry provide confidence in the assignment of this event to the sulfate ions binding to salmine chloride.

The MNIS model separately identified additional events below the UCST which occurred after $\mathrm{SO}_{4}{ }^{2-}$ binding. The MNIS model treats macromolecules as having multiple non-cooperative binding sites, however it can also be interpreted as multiple events, rather than multiple binding sites $[27,28]$. Accordingly, the second sequential event was endothermic, overall enthalpically unfavorable, entropically favorable, and provided the largest driving force for LLPS (Table 2, row 3). We interpret this event as heat flow due to the initial condensation of salmine sulfate, corresponding to the sudden clouding of the solution at the UCST (Figure 1B). The comparatively large gain in 
entropy suggested the reaction was driven by hydrophobic effects, specifically restructuring and dehydration of the salmine molecules in the complexes. The third event, interpreted as the coalescence of condensed salmine sulfate complexes into a liquid macrophase, was enthalpically driven (Table 2, row 4). The MNIS model did not assume the events were sequential, but the approximately 1000-fold higher $\mathrm{K}_{\mathrm{a}}$ associated with the second event suggests it occurred before the third, which is consistent with the inflections in the ITC data. The favorable enthalpy may be due to rearrangement between $\mathrm{Gdm}^{+}$pairs into intermolecular bridges or clusters. The assumptions and multiple event interpretations are validated by the close fit to the data obtained by summing the binding isotherms from both the one-site and multi-site models (Figure 4D, red curve).

\subsection{Condensation of Salmine Synthetic Analogs}

Poly(3-guanidinopropyl methacrylamide-co-acrylamide) random copolymers were synthesized (Supplemental Figure S1) as salmine analogs to investigate whether the primary sequence, residues other than arginine, the chirality of the polypeptide backbone, or the salmine $\mathrm{M}_{\mathrm{m}}$ monodisperisty were necessary, or contributed to LLPS. The first series, in which the guanidinopropyl sidechain concentration was varied from 10-65 mol \%, the copolymers are referred to as PGPMAXX, where XX designates the target $\mathrm{mol} \%$ of 3-guanidinopropyl sidechains. The target $\mathrm{M}_{\mathrm{m}}$ of the RAFT polymerization reactions was $20 \mathrm{~kg} \mathrm{~mol}^{-1}$. In the second series, referred to as pGPMA65-MWXX, where XX designates the $M_{m}$, the 3-guanidinopropyl was fixed at a target of $65 \mathrm{~mol} \%$, while the target $\mathrm{M}_{\mathrm{m}}$ was varied from 10 to $40 \mathrm{~kg} \mathrm{~mol}^{-1}$ (Supplemental Table S1).

Upon cooling from above the UCST, the PGPMAXX sulfate copolymers first condensed into cloudy solutions, then spontaneously settled and equilibrated into transparent homogeneous liquid macrophases within $24 \mathrm{~h}$ (not shown), similar to salmine sulfate (Figure 1). At $10 \mathrm{~mol} \% \mathrm{Gdm}^{+}$, the lowest tested, pGPMA10 sulfate condensed at $10{ }^{\circ} \mathrm{C}$. The UCST increased as the $\mathrm{mol} \%$ of the guanidinopropyl sidechains increased due to increased stabilization of the condensed phase by the greater concentration of $\mathrm{Gdm}^{+} / \mathrm{Gdm}^{+}$intermolecular interactions (Figure $5 \mathrm{~A}$ ). The UCST also depended on the copolymer $\mathrm{M}_{\mathrm{m}}$ (Figure $5 \mathrm{~B}$ ). With the $\mathrm{mol} \% \mathrm{Gdm}^{+}$approximately fixed, the UCST rose with increasing copolymer $\mathrm{M}_{\mathrm{m}}$, due to a stabilization of the condensed phase by a greater number of intermolecular associations. Salmine sulfate (square symbol) was close to the copolymer $\mathrm{M}_{\mathrm{m}}$ trendline. The pGMPMA65 copolymer, with a $\mathrm{Gdm}^{+}$sidechain concentration similar to salmine, condensed at $55^{\circ} \mathrm{C}$, ten degrees higher than salmine sulfate due to the higher $\mathrm{M}_{\mathrm{m}}, 21.7 \mathrm{~kg} \cdot \mathrm{mol}^{-1} \mathrm{vs} .4 .4 \mathrm{~kg} \cdot \mathrm{mol}^{-1}$. Chloride-induced LLPS of pGPMA65 (Figure 5C, circles) was also similar to salmine (Figure 5C, triangles), with LLPS beginning above $1.4 \mathrm{M} \mathrm{NaCl}$ and reaching almost $100 \%$ above $2 \mathrm{M}$.
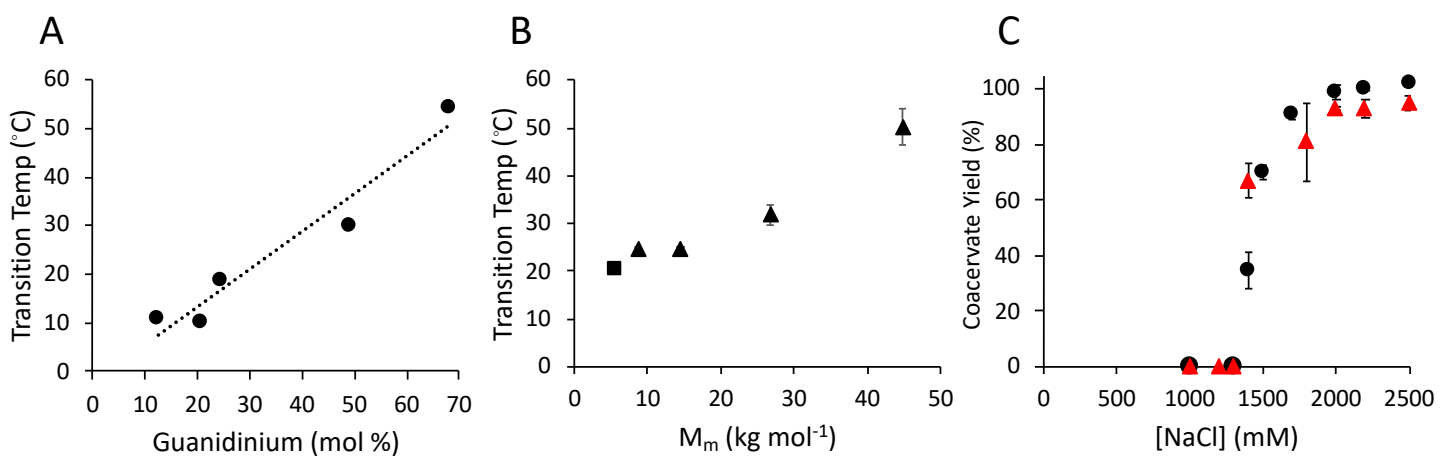

Figure 5. LLPS of pGPMA-co-acrylamide analogs of salmine determined by turbidimetry. (A) UCST dependence on $\mathrm{mol} \% \mathrm{Gdm}^{+}$. The copolymer concentrations were $50 \mathrm{mg} \cdot \mathrm{mL}^{-1}$. The $\mathrm{SO}_{4}{ }^{2-}: \mathrm{Gdm}^{+}$ ratio was 1:1. The dashed line was added to guide the eye. (B) UCST dependence on copolymer $\mathrm{M}_{\mathrm{m}}$. The copolymer concentrations (triangles) were $5 \mathrm{mg} \mathrm{mL}^{-1}$ and the $\mathrm{SO}_{4}{ }^{2-}: \mathrm{Gdm}^{+}$ratio was $1: 1$. Square symbol $=$ salmine sulfate at $5 \mathrm{mg} \mathrm{mL}^{-1}$ and the $\mathrm{SO}_{4}{ }^{2-}: \mathrm{Gdm}^{+}$ratio was $1: 1$. Mean $\pm 1 \mathrm{SD}(\mathrm{n}=3)$. (C) $\mathrm{NaCl}$ induced coacervation of pGPMA65 (triangles) and salmine (circles). Salmine $50 \mathrm{mg} \cdot \mathrm{mL}^{-1}$ at $8{ }^{\circ} \mathrm{C}$. Mean \pm 1 SD $(n=3)$. 
The similar phase behavior of synthetic poly $\left(\mathrm{Gdm}^{+}\right)$copolymers to natural salmine demonstrated that intermolecular associations between $\mathrm{Gdm}^{+}$groups alone are responsible for complexation and phase separation. The copolymers contain no negatively charged groups to participate in electrostatic interactions with the $\mathrm{Gdm}^{+}$sidechains, nor aromatic groups to participate in $\pi$-cation interactions. The achiral backbone and statistical order of monomers demonstrated that neither the chiral polypeptide backbone, nor amino acid sequence of salmine, is necessary for LLPS of polyguanidiniums. A full comparison of the synthetic copolymers to salmine with regard to other ion effects and thermodynamics were beyond the scope of this initial report.

\section{Discussion}

\section{The Molecular Mechanism of Polyguanidinium LLPS}

The absence of any negatively charged or aromatic residues in salmine or the pGPMA copolymers demonstrated condensation of poly $\left(\mathrm{Gdm}^{+}\right) \mathrm{s}$ was mediated strictly through $\mathrm{Gdm}^{+}$sidechains in the presence of divalent anions, such as sulfate and phosphate. The consistent 0.5 molar ratio of $\mathrm{SO}_{4}{ }^{2-}$ to R-Gdm ${ }^{+}$sidechains, whether calculated from ITC thermograms, or measured by elemental analysis of the condensed phase, demonstrated $\mathrm{SO}_{4}{ }^{2-}$ formed a specific chemical complex with pairs of $\mathrm{Gdm}^{+}$ groups. The energetics of $\mathrm{SO}_{4}{ }^{2-}$ binding to salmine had an overall favorable enthalpic contribution due perhaps to $\mathrm{H}$-bond formation between $\mathrm{SO}_{4}{ }^{2-}$ oxygens and $-\mathrm{NH}_{2}$ of $\left(\mathrm{R}-\mathrm{Gdm}^{+}\right)_{2}$, and an overall favorable gain in entropy due likely to the displacement of $\mathrm{Cl}^{-}$counterions and $\mathrm{H}$-bonded $\mathrm{H}_{2} \mathrm{O}$ molecules. Hydrophobic effects due to stacking of poorly hydrated R-Gdm ${ }^{+}$also likely contributes to the entropic driving force. Since the energetics were similar above and below the UCST, (Table 2) stoichiometric complex formation between $\mathrm{SO}_{4}{ }^{2-}$ and $\left(\mathrm{R}-\mathrm{Gdm}^{+}\right)_{2}$ does not lead directly to condensation and phase separation of salmine; the $\mathrm{R}-\mathrm{Gdm}^{+}$pairing must be largely intramolecular above the UCST (Figure 5A).

At and below the UCST, two additional transitons after $\mathrm{SO}_{4}{ }^{2-}\left(\mathrm{R}-\mathrm{Gdm}^{+}\right)_{2}$ complexation were discerned by interpreting the data as arising from two sequential events. The first sharp transition created visible light scattering salmine complexes. This initial intermolecular association of salmine sulfate is endothermic, slightly unfavorable enthalpically, and entropically driven, likely due to dehydration and exclusion of water from the complexes. The second, slower transition results in the coalescence of the initial complexes into a homogenous dehydrated liquid network.

The restructuring that occurs during the second transition is enthalpic, and may be driven by an exchange of intramolecular to intermolecular R-Gdm ${ }^{+}$pairs (Figure $5 \mathrm{~B}$ ), or higher-order R-Gdm ${ }^{+}$ stacking, i.e., $\left[\mathrm{Gdm}^{+}\right]_{x}$ clusters, as observed at the interface of multi-subunit proteins [29].

Condensation of R-rich proteins by high concentrations of $\mathrm{Cl}^{-}$is likely not relevant to biological LLPS mechanisms, and a detailed comparison of $\mathrm{Cl}^{-}$vs. $\mathrm{SO}_{4}{ }^{2-}$-induced LLPS was not a primary focus of this report. Nevertheless, chloride-induced LLPS of salmine was strikingly different than sulfate-induced LLPS; super-stochiometric concentrations were required to initiate phase separation, increasing $\mathrm{Cl}^{-}$concentrations stabilized the condensed state, as reflected in the increasing UCST (Figure 3B), and progressively increased dehydration of the condensed phase (Table 1). In contrast, the extent of LLPS of oppositely charged polyelectrolytes steadily decreases as ionic interactions between macroions are screened by increasing [ $\mathrm{NaCl}][30,31]$. The opposite effect of $\mathrm{NaCl}$ on salmine LLPS demonstrates that salmine self-association is not just carried out through simple electrostatic association of oppositely charged ions. Addition of low concentrations of $\mathrm{NaCl}$ to salmine sulfate decreased the stability of the salmine sulfate complexes, evident in the initial depression of the UCST, which then increased steadily above $\sim 800 \mathrm{mM} \mathrm{NaCl}$ (Figure 3C). It appears $\mathrm{SO}_{4}{ }^{2-}$ and $\mathrm{Cl}^{-}$ promote salmine condensation by different mechanisms. Compared to divalent sulfate anions, higher concentrations of monovalent $\mathrm{Cl}^{-}$may be required to sufficiently compensate or delocalize the positive charges of R-Gdm ${ }^{+}$to allow pairing that leads to salmine condensation and dehydration. Or, the effect 
of $\mathrm{Cl}^{-}$may be primarily on the solution-a salting out effect—enhanced by $\mathrm{Gdm}^{+}$pairing. In this context, chloride is in the middle of the Hofmeister series with relatively low ability to salt out proteins.

A molecular model of the proposed $\mathrm{SO}_{4}{ }^{2-}\left(\mathrm{Gdm}^{+}\right)_{2}$ stacking interactions, diagrammed in Figure 6, is derived from extensive evidence in the literature of $\mathrm{R}-\mathrm{Gdm}^{+}$contact pairing, the most compelling of which has been found in protein data bases [29,32]. A survey of the Brookhaven PDB by Scheraga's group, identified numerous examples of R-Gdm ${ }^{+}$pairs with less than $5 \AA$ center-to-center separation of the $\mathrm{R}-\mathrm{Gdm}^{+}$groups in protein structures [32]. The $\mathrm{Gdm}^{+}$pairs occurred as planar stacks equally distributed in two general orientations with respect to the long axis of the sidechain, parallel and anti-parallel. The stacks occurred in three rotational orientations with respect to the perpendicular axis of the $\mathrm{Gdm}^{+}$pairs, referred to as eclipsed, staggered, and half-staggered. The stacked pairs were stabilized by $\mathrm{H}$-bond bridges to $\mathrm{H}_{2} \mathrm{O}$ molecules and the Os of neighboring sidechains, in particular the carboxylates of glutamate and aspartate. Another PDB survey by Neves [29], identified over 70,000 examples of clustered Rs ( $<5 \AA$ separation), occurring frequently at the interfaces of multi-subunit protein complexes, organized into pairs, strings with up to 7 members, and rings of $4-8$ Rs. The R-Gdm ${ }^{+}$ groups were in stacked planar orientations, stabilized by H-bonds (5) with neighboring residues, water, or small anions.
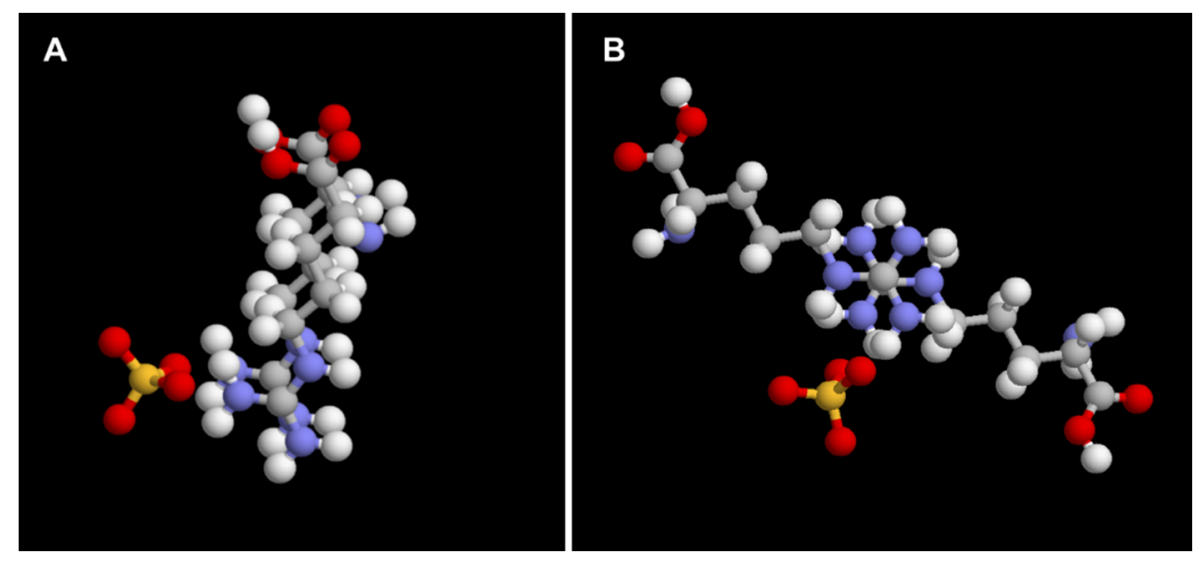

Figure 6. Parallel (A) and anti-parallel (B) stacking of $\mathrm{R}-\mathrm{Gdm}^{+}$sidechains in the presence of a sulfate molecule.

In addition to the empirical evidence found in protein crystal structures, numerous MD simulations [33-37] have provided computational evidence of like-charge contact ion pairing between $\mathrm{Gdm}^{+}, \mathrm{R}-\mathrm{Gdm}^{+}$, and oligo-R. Mason reported dynamic, nanometer-scale, network-like aggregations of $\mathrm{Gdm}^{+}$ion pairs in the presence of sulfate with lifetimes on the order of several tenths of a nanosecond [38]. Similarly, Schneider et al. described H-bonded, worm-like chains of arginines in the presence of phosphate, citrate, and sulfate anions, but not in the presence of acetate or chloride anions [39]. Of the simulated anions, sulfate had the strongest interactions with the R-Gdm ${ }^{+}$sidechains, consistent with the higher thermal stability (UCST) of the salmine sulfate complex coacervates we observed (Figure 3).

The counter-intuitive like-charge $\mathrm{Gdm}^{+}$and $\mathrm{R}-\mathrm{Gdm}^{+}$stacked pairs are explained by the unique structure and chemistry of the guanidino functional group. The guanidinium ion, comprising three amino groups bonded to a central carbon atom, has been described as Y-conjugated and quasi-aromatic [40,41]. The rigid, planar geometry restricts $\mathrm{H}$-bond donation by $\mathrm{Gdm}^{+}$and alkyl-Gdm ${ }^{+}$ sidechains (six and five, respectively), and strong interactions with water, to the molecular plane of the ions. The delocalization of the $\pi$ electron of the central $C$ gives it low positive charge density and makes it a poor $\mathrm{H}$-bond acceptor with $\mathrm{H}_{2} \mathrm{O}$. As a result, the top and bottom surfaces of the ion are unhydrated. $\mathrm{Gdm}^{+}$has been described as having essentially no hydration shell, and no effect on the structure or dynamics of water, based on neutron diffraction [42] and dielectric relaxation spectroscopy studies [43]. The main structural factors and forces that overcome electrostatic repulsion and stabilize the stacked 
$\mathrm{Gdm}^{+}$pairs have been summarized by Vazdar and colleagues [44]. First, electrostatic repulsion is minimized by distribution of the positive charge between the three resonance structures of the planar molecules and staggering of the $\mathrm{Gdm}^{+} \mathrm{Ns}$ by about $60^{\circ}$ in the perpendicular axis of the stacked pair. Second, the weak electrostatic repulsion between the low charge density cations is overcome by energetically favorable dispersion forces due to $\left(\mathrm{Gdm}^{+}\right)_{2}$ quadrapole-quadrapole interactions. Also, the excluded solvent volume, and associated energetic penalty, is lower for two or more stacked $\mathrm{Gdm}^{+}$ groups compared to single $\mathrm{Gdm}^{+}$, i.e., a hydrophobic driving force [33]. Additional stabilization is provided by $\mathrm{H}$-bond bridging of $\left(\mathrm{Gdm}^{+}\right)_{2}$ by water, neighboring residues, and small ions. Sulfate ions have the strongest stabilizing effect because of the highly favorable dimensions and tetrahedral geometry for bridging two $\mathrm{Gdm}^{+} \mathrm{s}$ [39].

Several of the proteins demonstrated to undergo LLPS in the cytoplasm and in vitro contain R-rich motifs, as well as aromatic residues (F, Y, and W) and acidic residues (D and E) [7-10,40,41]. In these cases, protein association has been attributed to electrostatic, $\pi$-cation, and $\pi-\pi$ interactions. Like-charge $\left(\mathrm{Gdm}^{+}\right)_{\mathrm{x}}$ interactions within and between R-rich motifs were not anticipated. Favorable $\mathrm{Gdm}^{+}$pairing in the presence of dianions is a mechanism in addition to electrostatic interactions that may contribute to LLPS. On the other hand, the R-rich repeating dipeptides deriving from GGGGCC hexanucleotide repeats associated with the gene C9orf72, contain only $\mathrm{R}$, and no other charged or aromatic residues $[18,19]$. The C9orf72 hexanucletotide expansions are the primary genetic cause of familial amyotrophic lateral sclerosis and frontotemporal dementia [17]. The hexanucleotide repeats are translated from five of the six reading frames into repeating dipeptides, one of which encodes $G_{n}$ and another encodes $\mathrm{PR}_{\mathrm{n}}$. The translated $\mathrm{R}$-rich repeating dipeptides associate with nucleoli, disrupt RNA synthesis, and cause cell death [18]. Synthetic $\mathrm{GR}_{20}$ and $\mathrm{PR}_{20}$ polypeptides phase separate into liquid droplets in vitro in the presence of $\mathrm{HPO}_{4}{ }^{2-}$, as well as in the presence of $30 \%$ PEG and poly-U RNA, a polyanion [45]. In the absence of other charged or aromatic residues, as with salmine and synthetic poly $\left(\mathrm{Gdm}^{+}\right)$, self-association of the toxic $\mathrm{PR}_{\mathrm{n}}$ and $\mathrm{GR}_{\mathrm{n}}$ must occur through $\mathrm{R}-\mathrm{Gdm}^{+}$pairing, although there may be other cellular factors involved.

\section{Conclusions}

The temperature-dependent condensation of salmine and synthetic polymer analogs into dense liquids is promoted by divalent dianions, such as sulfate and phosphate, and inhibited by monovalent anions such as chloride and acetate. The results provide empirical in vitro evidence of like-charge pairing between $\mathrm{Gdm}^{+}$groups and highlight another potential mechanism of cellular LLPS. The sensitivity to environmental conditions of the salmine and synthetic poly $\left(\mathrm{Gdm}^{+}\right)$condensation and phase transitions provides an experimental approach for additional study of anion effects, thermodynamics, and the structure of like-charge $\mathrm{Gdm}^{+}$ion pairing. The results strongly support the conclusions of others regarding the role of R-rich motifs in cellular LLPS, both regulated and pathological, providing additional details of the $\mathrm{Gdm}^{+}$self-association mechanism, and the potent effect of specific anions to be considered in future studies of cellular LLPS. Detailed understanding of the mechanisms of specific anion promotion or disruption of R-mediated phase transitions may be useful during the search for small molecule inhibitors of pathological LLPS. Finally, the in vitro LLPS of salmine raises the question of whether protamine LLPS plays a role in the condensation of chromatin during spermatogenesis.

Supplementary Materials: The following are available online at http://www.mdpi.com/2073-4360/11/4/649/s1, Figure S1: Synthesis of poly(3-guanidinopropyl methacrylamide-co-acrylamide) HCl, Table S1: 3-guanidinopropyl methacrylamide copolymers, Video S1: Salmine condensation and phase separation.

Author Contributions: Conceptualization, R.J.S.; Investigation, L.J.P, G.M.W., M.S. and C.Q.; Supervision, R.J.S.

Funding: This work was supported by grants from the National Institutes of Health (R01HD075863), Office of Naval Research (N000141612538), and the Army Research Office (W911NF-13-1-0319).

Conflicts of Interest: The authors declare no conflict of interest. 


\section{References}

1. Yevreinova, T.N. Concentration of Matter and Action of Enzymes in Coacervates; Nauka Press: Moscow, Russia, 1966.

2. De Kruif, C.G.; Weinbreck, F.; De Vries, R. Complex Coacervation of Proteins and Anionic Polysaccharides. Curr. Opin. Colloid Interface Sci. 2004, 9, 340-349. [CrossRef]

3. Brangwynne, C.P.; Tompa, P.; Pappu, R.V. Polymer physics of intracellular phase transitions. Nat. Phys. 2015, 11, 899-904. [CrossRef]

4. Song, I.T.; Stewart, R.J. Complex coacervation of $\mathrm{Mg}(\mathrm{II})$ phospho-polymethacrylate, a synthetic analog of sandcastle worm adhesive phosphoproteins. Soft Matter 2018, 14, 379-386. [CrossRef]

5. Hyman, A.A.; Weber, C.A.; Jülicher, F. Liquid-Liquid Phase Separation in Biology. Annu. Rev. Cell Dev. Biol. 2014, 30, 39-58. [CrossRef]

6. Sear, R.P. Phase separation of equilibrium polymers of proteins in living cells. Faraday Discuss. 2008, 139, 21-34. [CrossRef] [PubMed]

7. Mitrea, D.M.; Kriwacki, R.W. Phase separation in biology; functional organization of a higher order. Cell Commun. Signal. 2016, 14, 1-20. [CrossRef] [PubMed]

8. Shin, Y.; Brangwynne, C.P. Liquid phase condensation in cell physiology and disease. Science 2017, 357, eaaf4382. [CrossRef] [PubMed]

9. Aguzzi, A.; Altmeyer, M. Phase Separation: Linking Cellular Compartmentalization to Disease. Trends Cell Biol. 2016, 26, 547-558. [CrossRef]

10. Elbaum-Garfinkle, S.; Kim, Y.; Szczepaniak, K.; Chen, C.C.-H.; Eckmann, C.R.; Myong, S.; Brangwynne, C.P. The disordered $\mathrm{P}$ granule protein LAF-1 drives phase separation into droplets with tunable viscosity and dynamics. Proc. Natl. Acad. Sci. USA 2015, 112, 7189-7194. [CrossRef] [PubMed]

11. Nott, T.J.; Petsalaki, E.; Farber, P.; Jervis, D.; Fussner, E.; Plochowietz, A.; Craggs, T.D.; Bazett-Jones, D.P.; Pawson, T.; Forman-Kay, J.D.; et al. Phase Transition of a Disordered Nuage Protein Generates Environmentally Responsive Membraneless Organelles. Mol. Cell 2015, 57, 936-947. [CrossRef]

12. Qamar, S.; Wang, G.; Randle, S.J.; Ruggeri, F.S.; Varela, J.A.; Lin, J.Q.; Phillips, E.C.; Miyashita, A.; Williams, D.; Ströhl, F.; et al. FUS Phase Separation Is Modulated by a Molecular Chaperone and Methylation of Arginine Cation- $\pi$ Interactions. Cell 2018, 173, 720-725. [CrossRef]

13. Varadi, M.; Zsolyomi, F.; Guharoy, M.; Tompa, P. Functional Advantages of Conserved Intrinsic Disorder in RNA-Binding Proteins. PLoS ONE 2015, 10, e0139731. [CrossRef] [PubMed]

14. Burke, K.A.; Janke, A.M.; Rhine, C.L.; Fawzi, N.L. Residue-by-Residue View of In Vitro FUS Granules that Bind the C-Terminal Domain of RNA Polymerase II. Mol. Cell 2015, 60, 231-241. [CrossRef] [PubMed]

15. Rhoads, S.; Monahan, Z.; Yee, D.; Shewmaker, F. The Role of Post-Translational Modifications on Prion-Like Aggregation and Liquid-Phase Separation of FUS. Int. J. Mol. Sci. 2018, 19, 886. [CrossRef] [PubMed]

16. Hofweber, M.; Hutten, S.; Bourgeois, B.; Spreitzer, E.; Niedner-Boblenz, A.; Schifferer, M.; Ruepp, M.D.; Simons, M.; Niessing, D.; Madl, T.; et al. Phase Separation of FUS Is Suppressed by Its Nuclear Import Receptor and Arginine Methylation. Cell 2018, 173, 706-719. [CrossRef]

17. DeJesus-Hernandez, M.; Mackenzie, I.R.; Boeve, B.F.; Boxer, A.L.; Baker, M.; Rutherford, N.J.; Nicholson, A.M.; Finch, N.A.; Flynn, H.; Adamson, J.; et al. Expanded GGGGCC Hexanucleotide Repeat in Noncoding Region of C9ORF72 Causes Chromosome 9p-Linked FTD and ALS. Neuron 2011, 72, 245-256. [CrossRef] [PubMed]

18. Kwon, I.; Xiang, S.; Kato, M.; Wu, L.; Theodoropoulos, P.; Wang, T.; Kim, J.; Yun, J.; Xie, Y.; McKnight, S.L. Poly-dipeptides encoded by the C9orf72 repeats bind nucleoli, impede RNA biogenesis, and kill cells. Science 2014, 345, 1139-1145. [CrossRef] [PubMed]

19. Lee, K.H.; Zhang, P.; Kim, H.J.; Mitrea, D.M.; Sarkar, M.; Freibaum, B.D.; Cika, J.; Coughlin, M.; Messing, J.; Molliex, A.; et al. C9orf72 Dipeptide Repeats Impair the Assembly, Dynamics, and Function of Membrane-Less Organelles. Cell 2016, 167, 774-788. [CrossRef]

20. Balhorn, R. The protamine family of sperm nuclear proteins. Genome Biol. 2007, 8, 227. [CrossRef]

21. Kossel, A. The Protamines and Histones; Longmans Green and Co.: London, UK, 1928.

22. Sautière, P.; Briand, G.; Gusse, M.; Chevaillier, P. Primary structure of the protamine isolated from the sperm nuclei of the dog-fish Scylliorhinus caniculus. Eur. J. Biochem. 1981, 119, 251-255. [CrossRef] 
23. Watanabe, R.; Suzuki, T.; Oshima, Y. Development of quantitative NMR method with internal standard for the standard solutions of paralytic shellfish toxins and characterisation of gonyautoxin- 5 and gonyautoxin- 6 . Toxicon 2010, 56, 589-595. [CrossRef] [PubMed]

24. Freire, E.; Mayorga, O.L.; Straume, M. Isothermal Titration. Anal. Chem. 1990, 62, 950-959. [CrossRef]

25. Bernatowicz, M.S.; Wu, Y.; Matsueda, G.R. 1H-Pyrazole-1-carboxamidine hydrochloride an attractive reagent for guanylation of amines and its application to peptide synthesis. J. Org. Chem. 1992, 57, 2497-2504. [CrossRef]

26. Yonamine, Y.; Yoshimatsu, K.; Lee, S.H.; Hoshino, Y.; Okahata, Y.; Shea, K.J. Polymer Nanoparticle-Protein Interface. Evaluation of the Contribution of Positively Charged Functional Groups to Protein Affinity. ACS Appl. Mater. Interfaces 2013, 5, 374-379. [CrossRef]

27. Kayitmazer, A.B. Thermodynamics of complex coacervation. Adv. Colloid Interface Sci. 2017, 239, 169-177. [CrossRef] [PubMed]

28. Aberkane, L.; Jasniewski, J.; Gaiani, C.; Scher, J.; Sanchez, C. Thermodynamic Characterization of Acacia Gum- $\beta$-Lactoglobulin Complex Coacervation. Langmuir 2010, 26, 12523-12533. [CrossRef] [PubMed]

29. Neves, M.A.C.; Yeager, M.; Abagyan, R. Unusual Arginine Formations in Protein Function and Assembly: Rings, Strings, and Stacks. J. Phys. Chem. B 2012, 116, 7006-7013. [CrossRef]

30. Spruijt, E. Strength, Structure and Stability of Polyelectrolyte Complex Coacervates. Ph.D. Thesis, Wageningen University, Wageningen, The Netherlands, 2012.

31. Wang, Q.; Schlenoff, J.B. The Polyelectrolyte Complex/Coacervate Continuum. Macromolecules 2014, 47, 3108-3116. [CrossRef]

32. Magalhaes, A.; Maigret, B.; Hoflack, J.; Gomes, J.N.; Scheraga, H.A. Contribution of unusual arginine-arginine short-range interactions to stabilization and recognition in proteins. J. Protein Chem. 1994, 13, 195-215. [CrossRef]

33. Vondrášek, J.; Mason, P.E.; Heyda, J.; Collins, K.D.; Jungwirth, P. The Molecular Origin of Like-Charge Arginine-Arginine Pairing in Water. J. Phys. Chem. B 2009, 113, 9041-9045. [CrossRef]

34. No, K.T.; Nam, K.-Y.; Scheraga, H.A. Stability of Like and Oppositely Charged Organic Ion Pairs in Aqueous Solution. J. Am. Chem. Soc. 1997, 119, 12917-12922. [CrossRef]

35. Vazdar, M.; Uhlig, F.; Jungwirth, P. Like-Charge Ion Pairing in Water: An Ab Initio Molecular Dynamics Study of Aqueous Guanidinium Cations. J. Phys. Chem. Lett. 2012, 3, 2021-2024. [CrossRef]

36. Mason, P.E.; Neilson, G.W.; Enderby, J.E.; Saboungi, M.-L.; Dempsey, C.E.; MacKerell, A.D.; Brady, J.W. The Structure of Aqueous Guanidinium Chloride Solutions. J. Am. Chem. Soc. 2004, 126, 11462-11470. [CrossRef] [PubMed]

37. Boudon, S.; Wipff, G.; Maigret, B. Monte Carlo Simulations on the Like-Charged Guanidinium-Guanidinium Ion Pair in Water. J. Phys. Chem. 1990, 94, 6056-6061. [CrossRef]

38. Mason, P.E.; Neilson, G.W.; Dempsey, C.E.; Brady, J.W. Nanometer-Scale Ion Aggregates in Aqueous Electrolyte Solutions: Guanidinium Sulfate and Guanidinium Thiocyanate. J. Phys. Chem. B 2005, 109, 185-196. [CrossRef] [PubMed]

39. Schneider, C.P.; Shukla, D.; Trout, B.L. Arginine and the Hofmeister Series: The Role of Ion-Ion Interactions in Protein Aggregation Suppression. J. Phys. Chem. B 2011, 115, 7447-7458. [CrossRef] [PubMed]

40. Gund, P. Guanidine, trimethylenemethane, and" Y-delocalization." Can acyclic compounds have "aromatic" stability? J. Chem. Educ. 1972, 49, 100-103. [CrossRef]

41. Gobbi, A.; Frenking, G. Y-Conjugated Compounds: The Equilibrium Geometries and Electronic Structures of Guanidine, Guanidinium Cation, Urea, and 1,1-Diaminoethylene. J. Am. Chem. Soc. 1993, 115, 2362-2372. [CrossRef]

42. Mason, P.E.; Neilson, G.W.; Dempsey, C.E.; Barnes, A.C.; Cruickshank, J.M. The hydration structure of guanidinium and thiocyanate ions: Implications for protein stability in aqueous solution. Proc. Natl. Acad. Sci. USA 2003, 100, 4557-4561. [CrossRef]

43. Hunger, J.; Niedermayer, S.; Buchner, R.; Hefter, G. Are Nanoscale Ion Aggregates Present in Aqueous Solutions of Guanidinium Salts? J. Phys. Chem. B 2010, 114, 13617-13627. [CrossRef] [PubMed] 
44. Vazdar, M.; Heyda, J.; Mason, P.E.; Tesei, G.; Allolio, C.; Lund, M.; Jungwirth, P. Arginine "Magic": Guanidinium Like-Charge Ion Pairing from Aqueous Salts to Cell Penetrating Peptides. Acc. Chem. Res. 2018, 51, 1455-1464. [CrossRef] [PubMed]

45. Boeynaems, S.; Bogaert, E.; Kovacs, D.; Konijnenberg, A.; Timmerman, E.; Volkov, A.; Guharoy, M.; De Decker, M.; Jaspers, T.; Ryan, V.H.; et al. Phase Separation of C9orf72 Dipeptide Repeats Perturbs Stress Granule Dynamics. Mol. Cell 2017, 65, 1044-1055. [CrossRef] [PubMed] 